\title{
Effect of Addition of Jelly and Storage Time on the Number of Lactic Acid Bacteria in Yoghurt Processed Products
}

\author{
Retno Martini Widhyasih", Jusuf Kristianto ${ }^{1}$, Lutfi Rahmawati Lubis ${ }^{1}$, Mega Mirawati ${ }^{1}$, Atik Hodikoh ${ }^{2}$, Rahmi Susanti ${ }^{1}$ \\ Gurid PE Mulyo ${ }^{3}$ iD \\ ${ }^{1}$ Department of Medical Laboratory Technology, Health Polytechnic Ministry of Health Jakarta III, Bekasi, Indonesia; ${ }^{2}$ Department \\ of Nursing, Health Polytechnic Ministry of Health Bandung, Bandung, Indonesia; ${ }^{3}$ Department of Nutrition, Health Polytechnic \\ Ministry of Health Bandung, Bandung, Indonesia
}

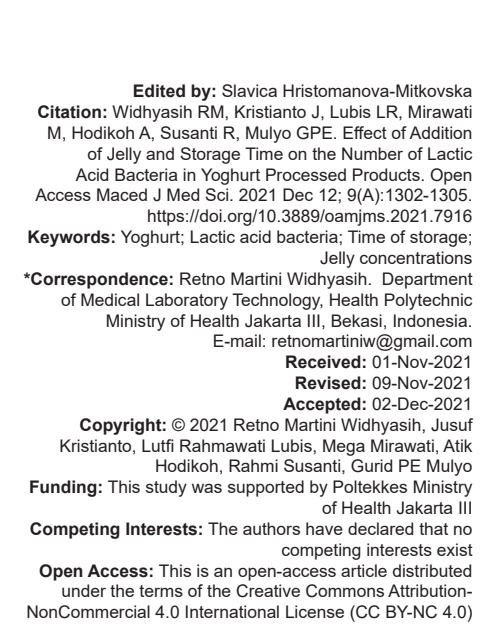

Introduction

Public awareness of the importance of health and nutritional adequacy in consuming foodstuffs makes them aware of drinking milk. Milk is one of the highly nutritious food ingredients because it contains complete and balanced food substances such as protein, fat, carbohydrates, minerals, and Vitamins that humans need. However, with the many benefits obtained from milk, there is a weakness in milk, which is easily damaged in a short time, so that milk becomes unfit for consumption if not appropriately handled. The development of modern technologies, so that by processing milk, you can get diverse and resistant to storage, one of which is yoghurt products [1].

Yoghurt is a fermented product that involves the services of microorganisms, namely bacteria.
Yoghurt is formed from lactic acid bacteria (LAB), namely Lactobacillus bulgaricus, Lactobacillus acidophilus and Streptococcus thermophilus are beneficial for health because they create a balance of intestinal microflora. The acidity produced can inhibit disease-causing bacteria, which are generally not resistant to acid. Fermentation is one of the technologies for preserving and processing milk; organic acids will be formed during fermentation, giving a distinctive taste to yoghurt. In addition, yoghurt has a unique freshness, aroma and flavour, namely sour and sweet [2].

LAB can produce antimicrobial compounds antagonistic to pathogenic bacteria, especially bacteriocins [3]. LAB are divided into two groups, namely homofermentative bacteria and heterofermentative bacteria. Homofermentative bacteria are bacteria capable of fermenting lactose and producing $85 \%$ lactic acid. Heterofermentative bacteria are bacteria capable 
of fermenting lactose and producing $40 \%$ lactic acid and $60 \%$ acetic acid [4].

In the yoghurt fermentation process, LAB require a substrate for their growth. The natural sugar content of milk is minimal, so it is necessary to add other substrates, including jelly, which microorganisms can directly utilize for their growth [5]. Jelly is made with a hydrocolloid material, which, when mixed with water, will produce a chewy texture as a characteristic of jelly [6]. This study aims to determine the effect of adding jelly with various concentrations and storage time on the number of $L A B$ in processed yoghurt products.

\section{Methods}

This research was conducted using an experimental method with descriptive narrative data analysis. The plate count method and a completely randomized design with a factorial pattern measure the total LAB. Factor I is the jelly concentration $(0.5 \%$, $0.75 \%$ and $1 \%$ ), and factor II is storage time (7 days, 14 days, 21 days at $\left.2-8^{\circ} \mathrm{C}\right)$. The combination of treatments from this study was $3 \times 3=9$ using three replications so that 27 trials were obtained. The research was carried out in April-June 2021 at the Microbiology Laboratory of the Health Polytechnic of the Ministry of Health, Jakarta III. The yoghurt used in this study has undergone an organoleptic test using the guide for making mother yoghurt by Widhyasih (2020) [7]. Yougermet ${ }^{\circledR}$ commercial starter bacteria used contains three bacteria, namely L. bulgaricus, S. thermophilus, and $L$. acidophilus. L. bulgaricus and $S$. thermophilus is a combination of bacteria with symbiotic properties in milk medium.

Data analysis used univariate and bivariate analysis to analyze each variable including the amount of LAB at each jelly concentration and the length of storage days. Test the amount of LAB before doing the bivariate analysis; first, the data normality test was

Table 1: Characteristics of isolates obtained from processed yoghurt

\begin{tabular}{lll}
\hline Bacteria & Bacteria test & Isolate characteristics \\
\hline Streptococcus thermophilus & Macroscopic & $\begin{array}{l}\text { Transparent, milky white, } \\
\text { round, flat and convex edges } \\
\text { Coccus chain }\end{array}$ \\
& Macroscopic & $\begin{array}{l}\text { Positive } \\
\text { Gram }\end{array}$ \\
Lactobacillus acidophilus & Macroscopic & $\begin{array}{l}\text { Transparent, beige, irregular } \\
\text { round, small and flat }\end{array}$ \\
& Macroscopic & $\begin{array}{l}\text { Basil chain } \\
\text { Positive }\end{array}$ \\
& Gram & $\begin{array}{l}\text { Transparent, beige, irregular } \\
\text { round, small and flat } \\
\text { Bastobacillus bulgaricus } \\
\text { Macroscopic }\end{array}$ \\
& Macroscopic & Positive \\
\hline
\end{tabular}

carried out, namely the Shapiro Wilk test. The test results for the number of BAL data are normal, then a two-way analysis of variance (ANOVA) test is carried out, followed by Duncan's Multiple Range Test.

\section{Results and Discussion}

\section{Yoghurt bacteria isolation}

Yoghurt processed products with the addition of jelly of various concentrations and stored at a temperature of $2-8^{\circ} \mathrm{C}$ for 7 days, 14 days and 21 days, then isolated on de Man, Rogosa Sharpe (MRS Agar) media, incubates $2 \times 24 \mathrm{~h}$ at $37^{\circ 0} \mathrm{C}$. The characteristics of the isolates obtained from processed yogurt can be seen in Table 1.

\section{Total LAB test}

Based on the study results, the number of $L A B$ from mother yoghurt is shown in Table 2.

Table 2: The population of preliminary cultures of lactic acid bacteria from Mother Yoghurt

\begin{tabular}{ll}
\hline Starter & Pre-population CFU/mL \\
\hline Yougermet $($ is a mixture of bacteria Streptococcus & $5.9 \times 10^{8}$ \\
thermophilus, Lactobacillus bulgaricus and & \\
Lactobacillus acidophilus & \\
\hline
\end{tabular}

In Table 2, the $\mathrm{LAB}$ test results on starter mother yoghurt are $10^{8} \mathrm{CFU} / \mathrm{mL}$. It indicates that the starter used has met the minimum quantity requirement of SNI 2981-2009 of $10^{7} \mathrm{CFU} / \mathrm{ml}$ [8]. Processed yoghurt in this study was then given the addition of variations in jelly concentrations of $0.5 \%, 0.75 \%$, and $1 \%$ and stored for 7 days, 14 days and 21 days at a temperature of $2-8^{\circ} \mathrm{C}$. The results of the analysis of the amount of $\mathrm{LAB}$ in yoghurt with the addition of jelly based on the length of storage days can be seen in Table 3 .

Table 3: The number of LAB in yoghurt with various jelly concentrations and storage days

\begin{tabular}{lll}
\hline Storage time (day) & Jelly concentration $(\%)$ & Number of LAB $(\mathrm{CFU} / \mathrm{mL})$ \\
\hline & Yoghurt (without jelly as control) & $5.9 \times 10^{8}$ \\
7 & Yoghurt with $0.5 \%$ jelly addition & $1.25 \times 10^{9}$ \\
7 & Yoghurt with $0.75 \%$ jelly addition & $2.16 \times 10^{9}$ \\
7 & Yoghurt with $1 \%$ jelly addition & $2.51 \times 10^{9}$ \\
14 & Yoghurt with $0.5 \%$ jelly addition & $1.09 \times 10^{9}$ \\
14 & Yoghurt with $0.75 \%$ jelly addition & $1.82 \times 10^{9}$ \\
14 & Yoghurt with $1 \%$ jelly addition & $2.10 \times 10^{9}$ \\
21 & Yoghurt with $0.5 \%$ jelly addition & $3.2 \times 10^{8}$ \\
21 & Yoghurt with $0.75 \%$ jelly addition & $1.01 \times 10^{9}$ \\
21 & Yoghurt with $1 \%$ jelly addition & $1.46 \times 10^{9}$ \\
\hline LAB: Lactic acid bacteria. & &
\end{tabular}

Based on the study results, the number of $L A B$ in each treatment gave results that met the 
requirements of SNI 2981:2009, namely a minimum of $10^{7} \mathrm{CFU} / \mathrm{ml}$. Table 3 and Figure 1 show the average number of bacteria based on jelly concentration and length of storage days; the highest number was on day 7 with a concentration of $1 \%$ with a total of $2.51 \times 10^{9}$, while on day 21 with a concentration of $0.5 \%$ has the least number of $L A B$, which is $3.2 \times 10^{8}$.

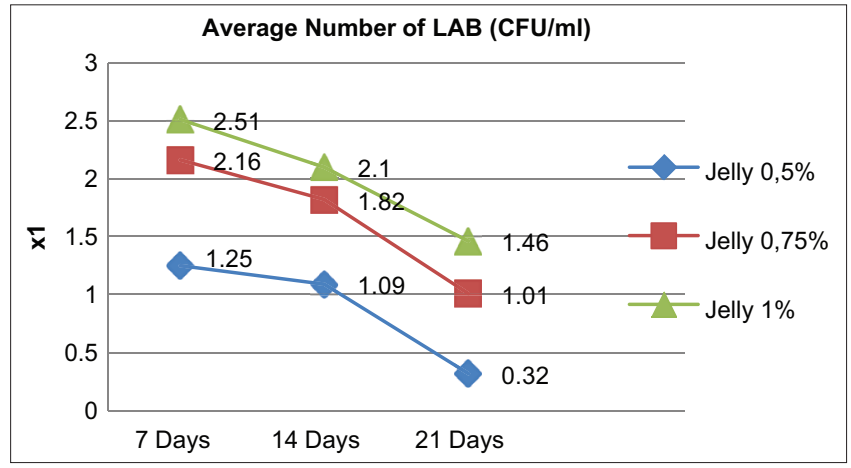

Figure 1: The number of lactic acid bacteria in yoghurt with various jelly concentrations and storage days

Before carrying out the two-way ANOVA test, the data must be tested for normality of data distribution and homogeneity of data variation. Both tests show a significance value $>0.00$, then proceed to the two way ANOVA test, as shown in Table 4.

Table 4: Two-way ANOVA test results on jelly concentration and storage time

\begin{tabular}{ll}
\hline Intervention & p-value \\
\hline Jelly concentration & 0.00 \\
Storage time & 0.00 \\
\hline
\end{tabular}

Table 4 shows the results of the two way ANOVA test with a significant level (95\%). It is known that the results of significance (Sig), namely, the storage time and jelly concentration are $0.00(<0.05)$. It can be stated that there is a significant effect on each treatment, namely by adding jelly concentration and storage time to the amount of LAB. Then continued Duncan's Multiple Range Test to determine the difference in total $L A B$ for each treatment.

Table 5 shows the results of Duncan's Multiple Range Test. It can be seen that the difference in storage time for yoghurt on day 7 , day 14 and day 21 shows that the total $L A B$ on day 7 is significantly different from day 14 and day 21, the longer it takes. Storage had a significant effect on the decrease in total LAB because the total $L A B$ was highest with a storage time of 7 days. The decrease in $L A B$ was due to the formation of metabolites and nutrients in the media utilized.

Table 5: Differences in the number of lactic acid bacteria based on storage days

\begin{tabular}{lc}
\hline Intervention & p-value \\
\hline Day 7 & $100.78^{\mathrm{a}}$ \\
Day 14 & $70.94^{\mathrm{b}}$ \\
Day 21 & $36.67^{\mathrm{c}}$ \\
\hline DMRT test rate 5\%. &
\end{tabular}

In Table 6 shows the results of Duncan's Multiple Range Test. It can be seen that the difference in yoghurt with jelly concentrations of $0.5 \%, 0.75 \%$, and $1 \%$ from the results of Duncan's Multiple Range Test shows that the total LAB at a jelly concentration of $0.5 \%$ is not different significantly different from the jelly concentration of $0.75 \%$. In comparison, it was significantly different at $1 \%$ jelly concentration with the jelly concentration of $0.5 \%$ and 0.75 jelly.

Table 6: Differences in the number of lactic acid bacteria based on the concentration of jelly

\begin{tabular}{ll}
\hline Intervention & $\mathrm{p}$-value \\
\hline Jelly $0,5 \%$ & $47.83^{\mathrm{a}}$ \\
Jelly $0,75 \%$ & $58.17^{\mathrm{a}}$ \\
Jelly $1 \%$ & $102.39^{\mathrm{b}}$ \\
\hline Values followed by the same letter show no significant difference in the 5\% DMRT test. &
\end{tabular}

It is in line with research from Pranayanti and Sutrisno (2015), which states that the decrease in the number of LAB is caused by a long fermentation time but is not balanced by the availability of sufficient nutrients. Some gram-positive, require intake of essential amino acids and $B$ vitamins in addition to carbohydrates [9].

Research results of Wirawati and Purwani (2019) explains that the highest total LAB with a storage time of 7 days, the decrease in $L A B$ is due to the formation of metabolites and nutrients utilized in the media [10]. Another study conducted by Harjantini and Rustanti (2015) stated that at concentrations $>0.5 \%$, the amount of jelly available in the ingredients could be sufficient for LAB to function optimally [5]. Several factors can cause the increase and decrease in the number of $L A B$, one of which is the fermentation factor, namely incubation, storage time, and the temperature used is $2-8^{\circ} \mathrm{C}[10]$.

\section{Conclusion}

This study concluded that the highest number of $L A B$ was found in the addition of $1 \%$ jelly with a storage time of 7 days with a total LAB yield of $2.51 \times 10^{9}$ $\mathrm{CFU} / \mathrm{mL}$. Storage time on day 7 , day 14 and day 21 and jelly concentrations of $0.5 \%, 0.75 \%$, and $1 \%$ added to processed yoghurt had a significant effect $(p<0.05)$ on the total number of LAB $(p<0.05) L A B)$.

\section{References}

1. Tambunan AR. Characteristics of Probiotics of Various Types of Lactic Acid Bacteria (LAB) in Pineapple Juice Lactate Fermented Drinks. Indonesia: Lampung University; 2016.

2. Hasfah A. The Effect of Starter Variations on the Quality of Cow's Milk Yoghurt. Makassar: Alauddin State Islamic University Makassar; 2012.

3. Widhyasih RM, Lestari E. Effect of Time, Fermentation 
Temperature, Type of Milk on the Number of Lactic Acid Bacteria and Yoghurt Organoleptic Quality, Final Report of Research Results, Poltekkes Ministry of Health Jakarta III; 2020.

4. Sandi IM, Bachtiar H, Hidayati. Comparison of the inhibitory effectiveness of curd with yoghurt against the growth of mutant streptococcus bacteria. J B Dent. 2015;2(2):88-94.

5. Harjantini U, Rustanti N. Total lactic acid bacteria, $\mathrm{Ph}$, and fiber content of srikaya jelly yoghurt functional drink with the addition of carrageenan. J Nutr Coll. 2015;4(2):514-9 Available from: http:// www.ejournal-s1.undip.ac.id/index.php/jnc. [Last accessed on 2021 Oct 20]. https://doi.org/10.14710/jnc.v4i4.10156

6. Khaliq A. The Effect of Using Rosella and Adding Different Sugars on Organoleptic Quality and Vitamin C Levels of Rosella (Hibiscus sabdarrifa L.) jelly drink. Semarang: State University of Semarang; 2011.

7. Widhyasih RM. "Mother Yoghurt" Starter Making Guide Poltekkes Ministry of Health Jakarta III; 2020. Available from: https://www.youtube.com/ watch?v=ozx3dnziw3u. [Last accessed on 2021 Oct 21]

8. National Standardization Body. SNI 2981: 2009 Food and Beverage (Yoghurt Quality Requirements), Jakarta; 2009.

9. Pranayanti IA, Sutrisno A. Making young coconut water (Cocos nucifera L.) probiotic drink with lactobacillus casei strain shirota as a starter. J Food Agroind. 2015;3(2):763-72.

10. Wirawati I, Purwani E. Effect of Long Storage at Cold Temperatures On Ph Value, Total Acid and Number of Lactic Acid Bacteria Yoghurt Suweg Flour (Amorphophallus Campanulatus). Indonesia: Muhammadiyah Surakarta University; 2019. 